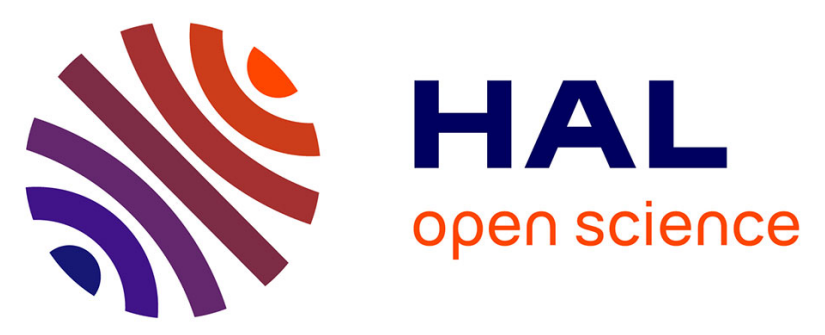

\title{
Synergistic Combination of Plasma Sputtered Pd-Au Bimetallic Nanoparticles for Catalytic Methane Combustion
}

Xiaoning Guo, Pascal Brault, Guojuan Zhi, Amaël Caillard, Guoqiang Jin, Christophe Coutanceau, Steve Baranton, Xiangyun Guo

\section{To cite this version:}

Xiaoning Guo, Pascal Brault, Guojuan Zhi, Amaël Caillard, Guoqiang Jin, et al.. Synergistic Combination of Plasma Sputtered Pd-Au Bimetallic Nanoparticles for Catalytic Methane Combustion. Journal of Physical Chemistry C, 2011, 115, pp.11240-11246. 10.1021/jp203351p . hal-00613848

\section{HAL Id: hal-00613848 https://hal.science/hal-00613848}

Submitted on 6 Aug 2011

HAL is a multi-disciplinary open access archive for the deposit and dissemination of scientific research documents, whether they are published or not. The documents may come from teaching and research institutions in France or abroad, or from public or private research centers.
L'archive ouverte pluridisciplinaire $\mathbf{H A L}$, est destinée au dépôt et à la diffusion de documents scientifiques de niveau recherche, publiés ou non, émanant des établissements d'enseignement et de recherche français ou étrangers, des laboratoires publics ou privés. 


\section{Synergistic Combination of Plasma Sputtered Pd-Au Bimetallic Nanoparticles for Catalytic Methane Combustion}

Xiaoning Guo ${ }^{\text {a,c }}$, Pascal Brault ${ }^{\text {b,* }}$ Guojuan Zhi ${ }^{\text {a,c }}$, Amaël Caillard ${ }^{\text {b }}$, Guoqiang Jin ${ }^{\text {a }}$, Christophe Coutanceau ${ }^{\mathrm{d}}$, Steve Baranton ${ }^{\mathrm{d}}$, Xiangyun Guo ${ }^{\mathrm{a}, *}$,

${ }^{a}$ State Key Laboratory of Coal Conversion, Institute of Coal Chemistry, Taiyuan 030001, PR China

b GREMI UMR6606 CNRS - Université d'Orléans BP6744, 45067 ORLEANS Cedex2, France

${ }^{\mathrm{c}}$ Graduate University of the Chinese Academy of Sciences, Beijing 100039, PR China

d LACCO, UMR6503 CNRS-Université de Poitiers, 40 avenue du Recteur Pineau, 86022 Poitiers, France

*Corresponding author:

Fax/Tel: +86-351 4065282

Email: xyguo@ sxicc.ac.cn (X. Y. Guo)

Fax: +33- 2384171 54; Tel: +33- 238417125

Email: Pascal.Brault@ univ-orleans.fr (P. Brault) 


\section{Abstract}

Pd-Au bimetallic nanoparticles supported by silicon carbide have been prepared by plasma sputtering deposition, and employed as the catalyst for methane combustion. It is found that the bimetallic nanoparticles consist of tight-coupled Pd and Au particles, which are neither Pd-Au alloyed nor core-shell structured. The catalytic activity increases with the Pd loading in the catalysts. When the temperature is higher than $520{ }^{\circ} \mathrm{C}, \mathrm{Pd}$ catalysts have an obvious drop in the catalytic activity due to the decomposition of $\mathrm{PdO}$. However the introduction of $\mathrm{Au}$ can delay and weaken the drop. It is indicated that there exists a synergistic combination between $\mathrm{Pd}$ and $\mathrm{Au}-$ oxygen transfers from $\mathrm{Pd}$ to $\mathrm{Au}$ at the temperature lower than $520{ }^{\circ} \mathrm{C}$ and from $\mathrm{Au}$ to Pd at higher temperature. Transmission electron microscopy and X-ray photoelectron spectroscopy results further confirm the synergistic combination.

Keywords: Pd-Au bimetallic catalysts; synergistic combination; methane combustion, plasma sputtering deposition. 


\section{Introduction}

Bimetallic nanoparticles have been known and exploited for many years in various catalytic reactions because catalytic performance, activity, selectivity, and stability can be enhanced compared to corresponding monometallic catalysts due to the synergistic combination of two metals ${ }^{1,2}$. Pd-Au bimetallic catalysts are particularly important because of their widespread applications in important industrial reactions, such as alcohol oxidation, $\mathrm{H}_{2} \mathrm{O}_{2}$ synthesis and toluene oxidation etc. ${ }^{3-8}$. Usually, the addition of $\mathrm{Au}$ can stabilize $\mathrm{Pd}$ components, lower the desorption temperature of reaction products and change the nature of active sites. Geometric, electronic and bifunctional effects have been proposed to explain the improvement of catalyst performance $^{9-11}$. However the influences of bimetallic structure and composition on the synergistic combination are still debated by researchers.

Various preparation techniques, such as coimpregnation, coprecipitation and fractional deposition etc., have been proposed for preparation of $\mathrm{Pd}-\mathrm{Au}$ bimetallic catalysts. However the composition, morphology, and electronic structure of bimetallic nanoparticles are markedly affected by preparation methods and experimental conditions. Recently, plasma sputtering has been studied extensively since the technique is feasible and no post-treatment is needed ${ }^{12,13}$. Most of these studies are related to production of ultra-fine monometallic particles and thin films, direct catalyst deposition on a support or assistance of catalytic reactions ${ }^{14-16}$. Many studies are devoted to preparation of bimetallic nanoparticles ${ }^{17-18}$, suggesting that 
plasma sputtering has obvious advantages in controlling the composition of bimetallic nanoparticles.

Catalytic combustion of lean natural gas and air mixture has attracted considerable attentions because the process operates at low temperature and produces little $\mathrm{NO}_{\mathrm{x}}$ emission ${ }^{19-23}$. The formulation of catalysts can be divided in low and high temperature catalysts which correspond to different stages in the catalytic combustion reactor. Supported palladium catalysts are usually used in the low temperature stage (400-900 ${ }^{\circ} \mathrm{C}$ ) to initiate methane ${ }^{24-26}$. However, the poor durability of Pd-based catalysts due to decomposition of $\mathrm{PdO}$ to $\mathrm{Pd}$ limits the development of catalytic combustion of methane $e^{27,28}$.

In this work, we prepared silicon carbide supported Pd-Au bimetallic nanoparticles using plasma sputtering technique and investigated the structure and composition of the bimetallic nanoparticles by transmission electron microscopy and X-ray photoelectron spectroscopy. The catalytic performance of the bimetallic nanoparticle catalysts for methane combustion indicates that there exists a synergistic combination between Pd and Au components.

\section{Experiments}

\subsection{Catalyst Preparation}

$\mathrm{Au}$ and Pd sputtering depositions are performed in a cylindrical stainless steel low pressure transformed coupled plasma device. The experimental setup dedicated to the study of metal cluster growth has been described elsewhere ${ }^{13,29,30}$. Briefly, argon plasma is created in a chamber using a planar external $\mathrm{RF}$ antenna $(13.56 \mathrm{MHz}$, 
$300 \mathrm{~W})$. The substrate used in this work is high surface area $\mathrm{SiC}^{31,32}$, which is prepared from a sol-gel and carbothermal reduction route and has a specific surface area of $50.8 \mathrm{~m}^{2} \mathrm{~g}^{-1}$ and a pore volume of $0.13 \mathrm{~m}^{3} \mathrm{~g}^{-1}$. The plasma depositions were performed under $\mathrm{P}=0.5 \mathrm{~Pa}$ and $\mathrm{V}_{\mathrm{b}}=-200 \mathrm{~V}$, where $\mathrm{P}$ is the Ar pressure (the base pressure is $5 \times 10^{-5} \mathrm{~Pa}$ ) and $\mathrm{V}_{\mathrm{b}}$ is the bias voltage of pure Au or Pd targets. The deposition time for $\mathrm{Au}$ and $\mathrm{Pd}$ is 7.5 minutes and 15 minutes, and corresponding samples are marked as $\mathrm{Au}_{0.6} / \mathrm{SiC}$ and $\mathrm{Pd}_{0.6} / \mathrm{SiC}$, where the subscript represents the metal loading. For preparing $\mathrm{Pd}_{0.4} \mathrm{Au}_{0.2} / \mathrm{SiC}$, the first step is 2.25 minutes for Au deposition and then 10.5 minutes for $\mathrm{Pd}$ deposition. For $\mathrm{Pd}_{0.2} \mathrm{Au}_{0.4} / \mathrm{SiC}$, the first step is 4.5 minutes for $\mathrm{Pd}$ deposition and then 5.25 minutes for Au deposition.

\subsection{Catalytic test}

The catalytic performance of different catalysts for the methane combustion was carried out in a fixed-bed quartz reactor with an inner diameter of $8 \mathrm{~mm}$ at atmospheric pressure, and the mixture of $\mathrm{O}_{2}(20 \%) / \mathrm{CH}_{4}(1 \%) / \mathrm{N}_{2}(79 \%)$ was used as the feedstock. $140 \mathrm{mg}$ of the catalyst was packed between two layers of quartz wool. The hourly space velocity was controlled to be $12500 \mathrm{~h}^{-1}$. Since the deactivation of the SiC-supported catalysts usually demands a long time, a repeated heating-then-cooling cycle method was employed to estimate the stability of different catalysts as previously reported ${ }^{33,34}$.

\subsection{Catalyst characterization}

The loadings of different metals in the catalysts were determined by Perkin-Elmer ELAN 5000 inductively coupled plasma-mass spectroscopy (ICP-MS) instrument and 
energy dispersive spectroscopy (EDS). The microstructures of the catalysts were analyzed by using JEM-2010 high-resolution transmission electron microscope (HRTEM). X-ray photoelectron spectroscopies (XPS) of different catalysts, which were taken at different temperatures in the catalytic combustion of methane, were measured on an ESCALAB 3 MKII de VG spectrometer by using $\mathrm{Mg} \mathrm{K \alpha}(15 \mathrm{kV}$, 20mA) X-ray source.

\section{Results and discussion}

\subsection{Catalytic performances}

The Au and Pd loadings determined by ICP-MS and EDS are listed in table 1. It can be seen that there exists subtle distinctions between the results from ICP-MS and EDS. Because the results from ICP-MS are more accurate, we employ them to represent the metal loadings. For example, in the catalyst $\mathrm{Pd}_{0.4} \mathrm{Au}_{0.2} / \mathrm{SiC}$, the loadings of $\mathrm{Pd}$ and $\mathrm{Au}$ are $0.4 \%$ and $0.2 \%$, respectively.

Fig. 1 shows the reaction results of methane combustion on $\mathrm{SiC}$ and $\mathrm{Au}_{0.6} / \mathrm{SiC}$. Usually the lowest fire point of $\mathrm{CH}_{4}$ is around $580{ }^{\circ} \mathrm{C}$ in air. In our experiments, $\mathrm{CH}_{4}$ could be ignited at $660{ }^{\circ} \mathrm{C}$ without any catalyst (only SiC), and the conversion could reach to $75 \%$ at $760{ }^{\circ} \mathrm{C}$ (Fig. 1a). However the selectivities of $\mathrm{CO}_{2}$ and $\mathrm{CO}$ are around $60 \%$ and $30 \%$, respectively (Fig. $1 \mathrm{~b}$ and $1 \mathrm{c}$ ). In other words, the combustion of methane is not complete at the experimental temperature if no metallic catalysts. When employing $\mathrm{Au}_{0.6} / \mathrm{SiC}$ as the catalyst, methane can be converted to $\mathrm{CO}_{2}$ with a selectivity of $100 \%$ at above $660{ }^{\circ} \mathrm{C}$ and the methane conversion can reach up to $100 \%$ at $760{ }^{\circ} \mathrm{C}$ (Fig. 1d and 1e). The above results indicate that Au supported on 
non-oxide materials also has a good catalytic activity for $\mathrm{CH}_{4}$ combustion at high temperature. The role of $\mathrm{Au}$ here is similar to that in $\mathrm{CO}$ oxidation. When the system temperature is higher than $660{ }^{\circ} \mathrm{C}$, methane is ignited and converted into $\mathrm{CO}_{2}, \mathrm{CO}$ and unburned hydrocarbons. The Au nanoparticles dispersed on $\mathrm{SiC}$ can dissociate $\mathrm{O}_{2}$ and produce dissociated oxygen species, which can oxidize $\mathrm{CO}$ and unburned hydrocarbons to $\mathrm{CO}_{2}$. Therefore the $\mathrm{CO}_{2}$ selectivity on $\mathrm{Au}_{0.6} / \mathrm{SiC}$ can get to $100 \%$.

Fig. 2 shows the methane conversions on different Pd-based catalysts. From Fig. 2a, the methane conversion on $\mathrm{Pd}_{0.6} / \mathrm{SiC}$ increases with the reaction temperature in a relatively low temperature range. When the temperature is higher than $520{ }^{\circ} \mathrm{C}$, however the methane conversion begins to decline. It is widely considered that the active phase of Pd-based catalysts in methane combustion is $\mathrm{PdO}$ and the declination is due to decomposition of $\mathrm{PdO}$ into $\mathrm{Pd}^{27,28}$. When employing bimetallic $\mathrm{Pd}-\mathrm{Au}$ catalysts, it means that partial $\mathrm{Pd}$ component in $\mathrm{Pd}_{0.6} / \mathrm{SiC}$ is replaced by $\mathrm{Au}$. Therefore, the activities of Pd-Au catalysts decrease obviously, as shown in Fig. $2 b$ and $2 c$. It is worth noting that both the activities of $\mathrm{Pd}_{0.4} \mathrm{Au}_{0.2} / \mathrm{SiC}$ and $\mathrm{Pd}_{0.2} \mathrm{Au}_{0.4} / \mathrm{SiC}$ are higher than that of $\mathrm{Pd}_{0.6} / \mathrm{SiC}$ below $370{ }^{\circ} \mathrm{C}$. This indicates that there may have a synergistic effect between $\mathrm{Pd}$ and $\mathrm{Au}$ components. In addition, the activities of $\mathrm{Pd}_{0.4} \mathrm{Au}_{0.2} / \mathrm{SiC}$ and $\mathrm{Pd}_{0.2} \mathrm{Au}_{0.4} / \mathrm{SiC}$ begin to decline at $560{ }^{\circ} \mathrm{C}$ and $580{ }^{\circ} \mathrm{C}$, respectively. Both of them are higher than that of $\operatorname{Pd}_{0.6} / \mathrm{SiC}\left(520{ }^{\circ} \mathrm{C}\right)$, indicating that the introduction of $\mathrm{Au}$ component can delay the declination temperature of Pd-based catalysts. Moreover, the decrements in the catalytic activity (methane conversion) are also less than that using 
$\mathrm{Pd}_{0.6} / \mathrm{SiC}$. These results suggest that the existence of $\mathrm{Au}$ could effectively hinder the decomposition of $\mathrm{PdO}$ to $\mathrm{Pd}$ at higher temperatures.

Methane conversions over the three Pd-based catalysts can reach to $100 \%$ at the temperature higher than $760{ }^{\circ} \mathrm{C}$. Such low loadings of Pd in the Pd-Au bimetallic catalysts, $0.4 \%$ and $0.2 \%$, can exhibit a catalytic activity as high as that of $\mathrm{Pd}_{0.6} / \mathrm{SiC}$, indicating that the $\mathrm{Au}$ component has played an important role in the catalytic reaction.

Fig. $3 \mathrm{a}$ and $3 \mathrm{~b}$ show the stabilities of $\mathrm{Pd}_{0.4} \mathrm{Au}_{0.2} / \mathrm{SiC}$ and $\mathrm{Pd}_{0.2} \mathrm{Au}_{0.4} / \mathrm{SiC}$ catalysts in the combustion of methane. Both catalysts can get to a $100 \%$ conversion at $760{ }^{\circ} \mathrm{C}$, which can remain unchanged after 10 reaction cycles. These indicate that the $\mathrm{SiC}$ supported catalysts have excellent stability for the catalytic combustion of methane and the high surface area $\mathrm{SiC}$ as the support can effectively stabilize $\mathrm{Pd}, \mathrm{Au}$ and Pd-Au bimetallic nanoparticles.

\subsection{HRTEM characterization}

Fig.4 shows HRTEM images of fresh and used $\mathrm{Pd}_{0.6} / \mathrm{SiC}$ catalysts. The used catalysts have completed 10 reaction cycles at $500{ }^{\circ} \mathrm{C}, 560{ }^{\circ} \mathrm{C}$ and $730{ }^{\circ} \mathrm{C}$ respectively. The lattice spacings of nanoparticles are around 0.224 and $0.282 \mathrm{~nm}$, which are indexed as (111) planes of $\mathrm{Pd}$ and (200) planes of PdO, respectively. Fig. 4a shows that $\mathrm{Pd}$ component in the fresh catalyst is metallic palladium, which results from the difference of plasma sputtering deposition and traditional coimpregnation or coprecipitation preparations. Fig.4b indicates that metallic Pd nanoparticles have been

completely oxidized into $\mathrm{PdO}$ at $500{ }^{\circ} \mathrm{C}$. From the HRTEM images shown in Fig. 4c 
and 4d, only metallic Pd particles can be found instead of PdO. These indicate that $\mathrm{PdO}$ can gradually decompose into $\mathrm{Pd}$ as the temperature is raised.

Fig.5 and Fig.6 show HRTEM images of fresh and used $\mathrm{Pd}_{0.4} \mathrm{Au}_{0.2} / \mathrm{SiC}$ and $\mathrm{Pd}_{0.2} \mathrm{Au}_{0.4} / \mathrm{SiC}$ catalysts, which have completed 10 reaction cycles at $560{ }^{\circ} \mathrm{C}, 600{ }^{\circ} \mathrm{C}$ and $760{ }^{\circ} \mathrm{C}$, respectively. In these figures, the lattice spacings of nanoparticles are around $0.235,0.224$, and $0.282 \mathrm{~nm}$, which correspond to (111) planes of $\mathrm{Au},(111)$ planes of Pd, and (200) planes of PdO, respectively. From Fig.5 and Fig.6, it is obvious that the bimetallic nanoparticles consist of tight-coupled Au and Pd particles and they are neither Pd-Au alloyed nor core-shell structured. There are obvious interfaces between $\mathrm{Au}$ and $\mathrm{Pd}$ components. From these images, the $\mathrm{Au}$ component always exists as the metallic phase whatever the temperature is. Contrarily, the $\mathrm{Pd}$ component undergoes a transformation of metal-oxide-metal along with the temperature variation. The transformation is mainly due to the oxidation of metallic $\mathrm{Pd}$ at low temperature and the decomposition of $\mathrm{PdO}$ at high temperature. In the image shown in Fig. 4c, metallic Pd particles can be easily found from used $\mathrm{Pd}_{0.6} / \mathrm{SiC}$ catalyst, indicating that $\mathrm{PdO}$ has decomposed into metallic $\mathrm{Pd}$ at $560{ }^{\circ} \mathrm{C}$. However $\mathrm{PdO}$ particles are still in the majority in the used bimetallic catalysts even though they have run at $600{ }^{\circ} \mathrm{C}$ for a long time (Fig.5c and Fig.6c). From table 1 and the HRTEM images, the average sizes of metal nanoparticles in all catalysts only have a slight increase after 10 reaction cycles, indicating that high surface area $\mathrm{SiC}$ based catalysts have excellent stabilities.

\subsection{XPS characterization}


Table 2 gives the results of XPS measurements. From table 2, Au $4 \mathrm{f}$ binding energy (BE) value at around $83.8 \mathrm{eV}$ can be attributed to $\mathrm{Au}^{0}$ charge state ${ }^{35}$, suggesting that $\mathrm{Au}$ can exist as metallic phase at any temperature. Combining with the catalytic performance of $\mathrm{Au}_{0.6} / \mathrm{SiC}$, the results of XPS further confirm that nanoscale $\mathrm{Au}$ particles have high-temperature activity for the catalytic combustion of methane even though they are supported by non-oxide materials such as SiC. Pd $3 d_{5 / 2}$ lines exhibit two peaks at $\mathrm{BE}$ values ranging in 334.7-335.1 eV and 337.6-337.8 eV, which can be attributed to $\mathrm{Pd}^{0}$ and $\mathrm{Pd}^{2+}$, respectively ${ }^{36-38}$. The $\mathrm{O} 1 \mathrm{~s} \mathrm{BE}$ value at about $529.1 \mathrm{eV}$ is attributed to the lattice oxygen associated with metal oxides, while the $\mathrm{O}$ 1s BE value at about $531.6 \mathrm{eV}$ is attributed to absorbed oxygen ${ }^{39}$. Comparing the fresh and used Pd-based catalysts at low temperatures $\left(500\right.$ and $\left.560{ }^{\circ} \mathrm{C}\right)$, it can be seen from Table 2 and Fig.7 that the concentrations of $\mathrm{Pd}^{2+}$ and lattice oxygen increase while the concentrations of absorbed oxygen decreases. The reason is due to the oxidation of metallic Pd in the reaction. For the Pd catalysts used at higher temperatures, the concentration of above three species change in opposite direction mainly due to the decomposition of $\mathrm{PdO}$. Although the concentrations of $\mathrm{Pd}^{2+}$ and lattice oxygen gradually decrease at high temperatures, both the decrements in $\mathrm{Pd}_{0.4} \mathrm{Au}_{0.2} / \mathrm{SiC}$ and $\mathrm{Pd}_{0.2} \mathrm{Au}_{0.4} / \mathrm{SiC}$ are less than the $\mathrm{Au}$-free $\mathrm{Pd}$ catalyst. Moreover, the more Au content is in the $\mathrm{Pd}-\mathrm{Au}$ catalysts, the less the $\mathrm{Pd}^{2+}$ content decreases.

The above results indicate that $\mathrm{Pd}-\mathrm{Au}$ bimetals in the catalytic process have synergistic effect apart from the specific performances of themselves. This can be 
interpreted by a simple model about the transference of dissociated oxygen species between $\mathrm{Pd}$ and Au during the reaction.

(a) At the temperature below $500{ }^{\circ} \mathrm{C}, \mathrm{O}_{2}$ can be dissociated and chemically adsorbed on $\mathrm{Pd}$ nanoparticles and form into $\mathrm{PdO}$. The formation rate of $\mathrm{PdO}$ increases rapidly with the temperature increasing. Meanwhile, the dissociation rate of $\mathrm{O}_{2}$ is much higher than the chemical adsorption rate of dissociated oxygen species on $\mathrm{Pd}$. And thus the concentration of dissociated oxygen species on Pd increases quickly. The additional oxygen species transfer from $\mathrm{Pd}$ to Au through interfaces of $\mathrm{Pd}$ and $\mathrm{Au}$, and $\mathrm{Au}$ here plays a role of reservoir for dissociated oxygen. As a result, the equilibrium favors the direction of $\mathrm{O}_{2}$ dissociation.

(b) $\mathrm{PdO}$ starts to decompose into $\mathrm{Pd}$ and $\mathrm{O}_{2}$ when the temperature is above $520{ }^{\circ} \mathrm{C}$. The decomposition rate of $\mathrm{PdO}$ becomes higher than the dissociation and chemical adsorption rate of $\mathrm{O}_{2}$. At this time, dissociated oxygen species transfer from the $\mathrm{Au}$ reservoir to $\mathrm{Pd}$ through $\mathrm{Pd}$ and $\mathrm{Au}$ interfaces because the metallic activity of $\mathrm{Pd}$ is higher than that of $\mathrm{Au}$. As a result, $\mathrm{PdO}$ as the active phase for methane combustion can keep relatively high concentration.

(c) At high temperature, e.g. above $660{ }^{\circ} \mathrm{C}, \mathrm{O}_{2}$ is dissociated and chemically adsorbed on Au nanoparticles due to the high-temperature activity ${ }^{40}$. The dissociated oxygen species on Au transfer to Pd through interfaces of Pd and Au. Therefore, both $\mathrm{Pd}$ and $\mathrm{Au}$ in the bimetallic catalysts can catalyze the combustion of methane through the synergistic combination.

\section{Conclusion}


Silicon carbide supported Pd-Au bimetallic nanoparticles were prepared by plasma sputtering deposition. The bimetallic particles have a tight-coupled structure. It is found that the introduction of Au can improve the catalytic performance of Pd-based catalysts for the catalytic combustion of methane. The improvement results from the synergistic combination between $\mathrm{Pd}$ and $\mathrm{Au}$ nanoparticles. At different reaction temperatures, the Au component plays roles of reservoir and provider of dissociated oxygen species, respectively. The average sizes of nanoparticles of all the SiC-based catalysts only have a slight increase suggesting that high surface area $\mathrm{SiC}$ could effectively hinder the migration and sintering of metal nanoparticles.

\section{Acknowledgments}

The work was financially supported by NSFC (Ref. 20973190), the in-house research project of SKLCC (Ref. SKLCC-2008BWZ010), and the National Basic Research Program (Ref. 2011CB201405).

\section{References}

(1) Fang, Y. L.; Miller, J. T .; N. Guo, Heck, K. N.; Alvarez, P. J. J.; Wong, M. S. Catal. Today 2011, 160, 96-102.

(2) Molenbroek, A. M.; Haukka, S.; Clausen, B. S. J. Phys. Chem. B 1998, 102, 10680-10689.

(3) Enache, D. I., Edwards, J. K., Landon, P., Solsona-Espriu, B., Carley, A. F., Herzing, A. A., Watanabe, M., Kiely, C. J., Knight, D. W., Hutchings, G. J. Science 2006, 311, 362-365.

(4) Edwards, J. K., Solsona, B., Ntainjua N, E., Carley, A. F., Herzing, A. A., Kiely, C. 
J., Hutchings, G. J. Science 2009, 323, 1037-1041.

(5) Kesavan, L., Tiruvalam, R., Rahim,M. H., Saiman, M. I., Enache, D. I., Jenkins, R. L., Dimitratos, N., Lopez-Sanchez, J. A., Taylor, S. H., Knight, D. W., Kiely, C. J., Hutchings, G. J. Science 2011, 331, 195-199.

(6) Wei, T.; Wang, J. H.; Goodman, D. W. J. Phys. Chem. C 2007, 111, 8781-8788.

(7) Li, G.; Edwards, J.; Carley, A. F.; Hutchings, G. J. Catal. Today 2007, 122, 361-364.

(8) Edwards, J. K.; Thomas, A.; Carley, A. F.; Herzing, A. A.; Kiely, C. J.; Hutchings, G. J. Green Chem. 2008, 10, 388-394.

(9) Chen, M. S.; Kumar, D. C.; Yi, W.; Goodman, D. W. Science 2005, 310, 291-293.

(10)Maroun, F.; Ozanam, F.; Magnussen, O. M.; Behm, R. J. Science 2001, 293, 1811-1814.

(11)Ponec, V. Appl. Catal. A. 2001, 222, 31-45.

(12)Chen, Q.; Zhang, Y. F.; Yang, L. Z.; Chen, S. G.; Weng, J.; Yue, L. J. Phys. Chem. C 2009, 113, 7633-7638.

(13)Rabat, H.; Andreazzac, C.; Brault, P.; Caillard, A.; Béguin, F.; Charles, C.; Boswell, R. Carbon 2009, 47, 209-214.

(14)Berthet, A.; Thomann, A. L.; Cadete Santos Aires, F. J.; Brun, M.; Deranlot, C.; Bertolini, J. C.; Rozenbaum, J. P.; Brault, P.; Andreazzaz, P. J. Catal. 2000, 190, 49-59.

(15)Xie, M.; Wang, J. S.; Khin Yap, Y. J. Phys. Chem. C 2010, 114, 16236-16241.

(16)Sonoda, T.; Watazu, A.; Zhu, J.; Kamiya, A.; Nonami, T.; Kameyama, T.; 
Naganuma, K.; Kato, M. Thin Solid Films 2001, 386, 227-232.

(17)Zhang, H. X.; Wang, C.; Wang, J. Y.; Zhai, J. J.; Cai, W. B. J. Phys. Chem. C 2010, $114,6446-6451$.

(18)Ito, Y.; Miyazaki, A.; Valiyaveettil, S.; Enoki, T. J. Phys. Chem. C 2010, 114, 11699-11702.

(19)Ciuparu, D.; Lyubovsky, M. R.; Altman, E.; Pfefferle, L. D.; Datye, A. Catal. Rev. 2002, 44, 593-649.

(20)Gélin, P.; Primet, M. Appl. Catal. B 2002, 39, 1-37.

(21)Zwinkels, M. F. M.; Järås, S. G.; Menon, P. G.; Griffin, T. A. Catal. Rev. 1993, $35,319-358$.

(22)Trimm, D. L. Appl. Catal. 1983, 7, 249-282.

(23)Quick, L. M.; Kamitomai, S. Catal. Today 1995, 26, 303-308.

(24)Pfefferle, L. D.; Pfefferle, W. C. Catal. Rev. 1987, 29, 219-267.

(25)Arai, H.; Fukuzawa, H. Catal. Today 1995, 26, 217-221.

(26)Euzen, P.; Le Gal, J. H.; Rebours, B.; Martin, G. Catal. Today 1999, 47, 19-27.

(27)Farrauto, R. J. ; Hobson, M. C. ; Kennelly, T.; Waterman, E. M. Appl. Catal. A 1992, $81,227-237$.

(28)Ozawa, Y.; Tochihara, Y.; Nagai, M.; Omi, S. Chem. Eng. Sci. 2003, 58, $671-677$.

(29)Rabat, H.; Brault, P. Fuel Cells 2008, 8, 81-86.

(30)Thomann, A. L.; Brault, P.; Rozenbaum, J. P.; Andreazza-Vignolle, C.; Andreazza, P.; Estrade-Szwarckopf, H.; Rousseau, B.; Babonneau,D.; 
Blondiaux,G. J. Phys. D: Appl. Phys. 1997, 30, 3197-3202.

(31)Jin, G. Q.; Guo, X. Y. Micropor. Mesopor. Mat. 2003, 60, 207-212.

(32)Guo, X. Y.; Jin, G. Q. J. Mater. Sci. 2005, 40, 1301-1303.

(33)Guo, X. N.; Shang, R. J.; Wang, D. H.; Jin, G. Q.; Guo, X. Y.; Tu, K. N. Nanoscale Res. Lett. 2010, 5, 332-337.

(34)X Guo,. N.; Zhi, G. J.; Yan, X. Y.; Jin, G. Q.; Guo, X. Y.; Brault, P. Catal. Commun. 2011, 12, 870-874.

(35)Choudhary, V. R.; V Patil,. P.; Jana, P.; Uphade, B. S. Appl. Catal. A 2008, 350, 186-190.

(36)Nelson, A. E. ; Schulz, K. H. Appl. Surf. Sci. 2003, 210, 206-221.

(37)Galtayries, A.; Sporken, R.; Riga, J.; Blanchard, G.; Caudano, R. J. Electron Spectrosc. Rel. Phen. 1998, 88, 951-956.

(38) Arai, H.; Machida, M. Catal. Today 1991, 10, 81-94.

(39)Wang, S. P.; Zheng, X. C.; Wang, X. Y.; Wang, S. R.; Zhang, S. M.; Yu, L. H.; Huang, W. P.; Wu, S. H. Catal. Lett. 2005, 105, 163-168.

(40)Grisel, R. J. H.; Kooyman, P. J.; Nieuwenhuys, B. E. J. Catal. 2000, 191, 430-437. 


\section{Tables}

Table $1 \mathrm{Au}$ and Pd loading of different catalysts and the average size of nanoparticles of different fresh and used catalysts.

\begin{tabular}{ccccccc}
\hline Samples & \multicolumn{2}{l}{ Au loading (wt.\%) } & \multicolumn{2}{l}{ Pd loading (wt.\%) } & \multicolumn{2}{c}{ Nanopaticle size (HRTEM) (nm) } \\
\cline { 2 - 7 } & ICP-MS & EDS & ICP-MS & EDS & $\begin{array}{c}\text { Fresh } \\
\text { catalyst }\end{array}$ & $\begin{array}{c}\text { Used catalyst } \\
\text { (after 10 cycles) }\end{array}$ \\
$\mathrm{Au}_{0.6} / \mathrm{SiC}$ & 0.61 & 0.54 & - & - & 4.17 & 4.89 \\
$\mathrm{Pd}_{0.6} / \mathrm{SiC}$ & - & - & 0.63 & 0.52 & 3.74 & 4.86 \\
$\mathrm{Pd}_{0.4} \mathrm{Au}_{0.2} / \mathrm{SiC}$ & 0.19 & 0.13 & 0.42 & 0.39 & 5.12 & 6.03 \\
$\mathrm{Pd}_{0.2} / \mathrm{Au}_{0.4} \mathrm{SiC}$ & 0.40 & 0.36 & 0.22 & 0.15 & 4.01 & 5.34 \\
\hline
\end{tabular}




\begin{tabular}{llllll}
\hline & \multicolumn{2}{l}{ O 1s $(\mathrm{O}-$-metal $)$} & $\mathrm{Au} 4 \mathrm{f}$ & $\mathrm{Pd} 3 \mathrm{~d}$ & \\
\cline { 2 - 6 } Samples & $\begin{array}{l}\text { lattice oxygen } \\
\mathrm{BE}(\mathrm{eV})^{\mathrm{a}}\end{array}$ & $\begin{array}{l}\text { adsorbed oxygen } \\
\mathrm{BE}(\mathrm{eV})\end{array}$ & $\mathrm{BE}(\mathrm{eV})$ & $\mathrm{Pd}^{0}$ & $\mathrm{Pd}^{2+}$ \\
& $529.1(4.3)^{\mathrm{b}}$ & $531.6(95.7)$ & 83.8 & - & $\mathrm{BE}(\mathrm{eV})$ \\
$\mathrm{Au}_{0.6} / \mathrm{SiC}(\mathrm{fresh})$ & $529.1(3.2)$ & $531.5(96.8)$ & 84.0 & - & - \\
$\mathrm{Au}_{0.6} / \mathrm{SiC}\left(760^{\circ} \mathrm{C}\right)^{\mathrm{c}}$ & $529.0(5.1)$ & $531.5(94.9)$ & - & $334.7(96.7)^{\mathrm{d}}$ & $337.7(3.3)$ \\
$\mathrm{Pd}_{0.6} / \mathrm{SiC}(\mathrm{fresh})$ & $529.1(67.9)$ & $531.7(32.1)$ & - & $334.7(6.4)$ & $337.8(93.6)$ \\
$\mathrm{Pd}_{0.6} / \mathrm{SiC}\left(500^{\circ} \mathrm{C}\right)$ & & & & & \\
\hline
\end{tabular}




\begin{tabular}{llllll}
\hline $\mathrm{Pd}_{0.6} / \mathrm{SiC}\left(560^{\circ} \mathrm{C}\right)$ & $529.0(51.5)$ & $531.6(48.5)$ & - & $335.0(21.9)$ & $337.6(78.1)$ \\
$\mathrm{Pd}_{0.6} / \mathrm{SiC}\left(730^{\circ} \mathrm{C}\right)$ & $529.2(29.8)$ & $531.7(70.2)$ & - & $334.8(34.6)$ & $337.6(65.4)$ \\
$\mathrm{Pd}_{0.4} \mathrm{Au}_{0.2} / \mathrm{SiC}(\mathrm{fresh})$ & $529.1(3.4)$ & $531.6(96.6)$ & 83.8 & $334.9(95.4)$ & $337.6(4.6)$ \\
$\mathrm{Pd}_{0.4} \mathrm{Au}_{0.2} / \mathrm{SiC}\left(560^{\circ} \mathrm{C}\right)$ & $529.0(48.6)$ & $531.6(51.4)$ & 83.9 & $334.7(5.1)$ & $337.8(94.9)$ \\
$\mathrm{Pd}_{0.4} \mathrm{Au}_{0.2} / \mathrm{SiC}\left(600^{\circ} \mathrm{C}\right)$ & $529.0(41.1)$ & $531.5(58.9)$ & 83.9 & $334.8(15.7)$ & $337.6(84.3)$ \\
$\mathrm{Pd}_{0.4} \mathrm{Au}_{0.2} / \mathrm{SiC}\left(760^{\circ} \mathrm{C}\right)$ & $529.1(37.4)$ & $531.7(62.6)$ & 84.0 & $334.7(23.3)$ & $337.6(76.7)$ \\
$\mathrm{Pd}_{0.2} \mathrm{Au}_{0.4} / \mathrm{SiC}(\mathrm{fresh})$ & $529.1(5.0)$ & $531.6(95.0)$ & 83.9 & $334.8(96.2)$ & $337.7(3.8)$ \\
$\mathrm{Pd}_{0.2} \mathrm{Au}_{0.4} / \mathrm{SiC}\left(560^{\circ} \mathrm{C}\right)$ & $529.1(33.9)$ & $531.6(66.1)$ & 84.0 & $334.9(3.5)$ & $337.8(96.5)$ \\
$\mathrm{Pd}_{0.2} \mathrm{Au}_{0.4} / \mathrm{SiC}\left(600^{\circ} \mathrm{C}\right)$ & $529.1(26.1)$ & $531.5(73.9)$ & 84.0 & $334.7(11.2)$ & $337.7(88.8)$ \\
$\mathrm{Pd}_{0.2} \mathrm{Au}_{0.4} / \mathrm{SiC}\left(760^{\circ} \mathrm{C}\right)$ & $529.0(21.3)$ & $531.7(78.7)$ & 84.0 & $334.9(19.4)$ & $337.7(80.6)$ \\
\hline
\end{tabular}

Table 2 Binding energies (eV) of $\mathrm{Au} 4 \mathrm{f}$ and $\mathrm{Pd} 3 \mathrm{~d}$ of different fresh and used catalysts which were taken at different temperatures in the $\mathrm{CH}_{4}$ methane catalytic combustion reaction.

a The binding energy (BE) values were corrected using the $\mathrm{C} 1 \mathrm{~s}$ peak at $285.0 \mathrm{eV}$.

$\mathrm{b}$ The value in the brackets refers to the relative content of the components of the $\mathrm{O}$ 1s (O-metal) spectra.

c The characterized samples were taken at the $760^{\circ} \mathrm{C}$ in the methane catalytic combustion reaction.d The value in the brackets refers to the relative content of the components of the Pd $3 \mathrm{~d}$ spectra.

\section{Figures captions:}

Fig.1 $\mathrm{CH}_{4}$ conversion and $\mathrm{CO}_{2}$ selectivity of $\mathrm{SiC}$ and $\mathrm{Au}_{0.6} / \mathrm{SiC}$ for methane combustion.

Fig.2 Catalytic activities of $\mathrm{Pd}_{0.6} / \mathrm{SiC}, \mathrm{Pd}_{0.4} \mathrm{Au}_{0.2} / \mathrm{SiC}$ and $\mathrm{Pd}_{0.2} \mathrm{Au}_{0.4} / \mathrm{SiC}$ for methane combustion.

Fig.3 Catalytic stabilities of $\mathrm{Pd}_{0.4} \mathrm{Au}_{0.2} / \mathrm{SiC}$ (a) and $\mathrm{Pd}_{0.2} \mathrm{Au}_{0.4} / \mathrm{SiC}$ (b) for methane 
combustion.

Fig.4 HRTEM images of fresh (a) and used $\mathrm{Pd}_{0.6} / \mathrm{SiC}$ catalysts which were taken at $500^{\circ} \mathrm{C}(\mathrm{b}), 560^{\circ} \mathrm{C}$ (c) and $730^{\circ} \mathrm{C}$ (d) respectively in the $\mathrm{CH}_{4}$ methane catalytic combustion reaction; and the size distribution of the nanoparticles.

Fig.5 HRTEM images of fresh (a) and used $\mathrm{Pd}_{0.4} \mathrm{Au}_{0.2} / \mathrm{SiC}$ catalysts which were taken at $560^{\circ} \mathrm{C}(\mathrm{b}), 600^{\circ} \mathrm{C}$ (c) and $760^{\circ} \mathrm{C}$ (d) respectively in the $\mathrm{CH}_{4}$ methane catalytic combustion reaction; and the size distribution of the nanoparticles.

Fig.6 HRTEM images of fresh (a) and used $\mathrm{Pd}_{0.2} \mathrm{Au}_{0.4} / \mathrm{SiC}$ catalysts which were taken at $560^{\circ} \mathrm{C}(\mathrm{b}), 600^{\circ} \mathrm{C}(\mathrm{c})$ and $760^{\circ} \mathrm{C}(\mathrm{d})$ respectively in the $\mathrm{CH}_{4}$ methane catalytic combustion reaction; and the size distribution of the nanoparticles.

Fig.7 XPS spectra of $\mathrm{O} 1 \mathrm{~s}$ of $\mathrm{Pd}_{0.6} / \mathrm{SiC}, \mathrm{Pd}_{0.4} \mathrm{Au}_{0.2} / \mathrm{SiC}$ and $\mathrm{Pd}_{0.2} \mathrm{Au}_{0.4} / \mathrm{SiC}$ which were taken at different temperature (before and after deactivation of catalysts. 


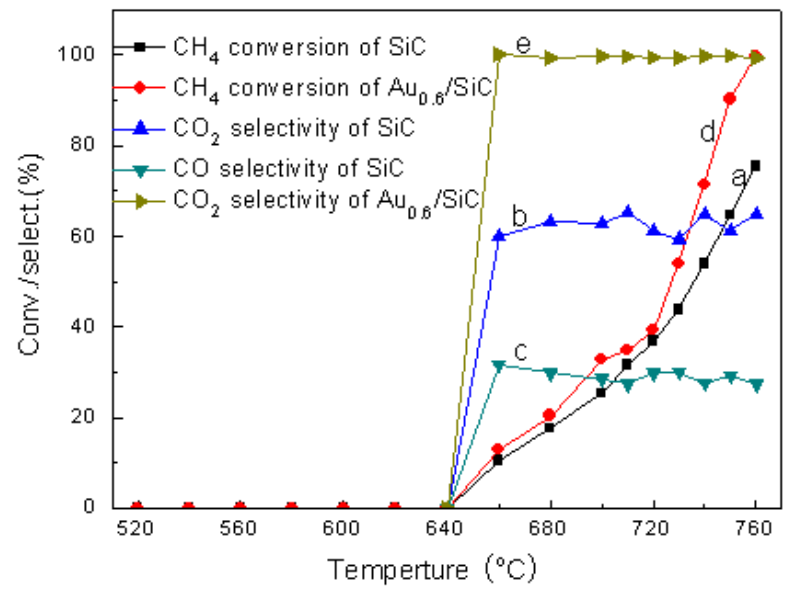

Fig.1 $\mathrm{CH}_{4}$ conversion and $\mathrm{CO}_{2}$ selectivity of $\mathrm{SiC}$ and $\mathrm{Au}_{0.6} / \mathrm{SiC}$ for methane combustion.

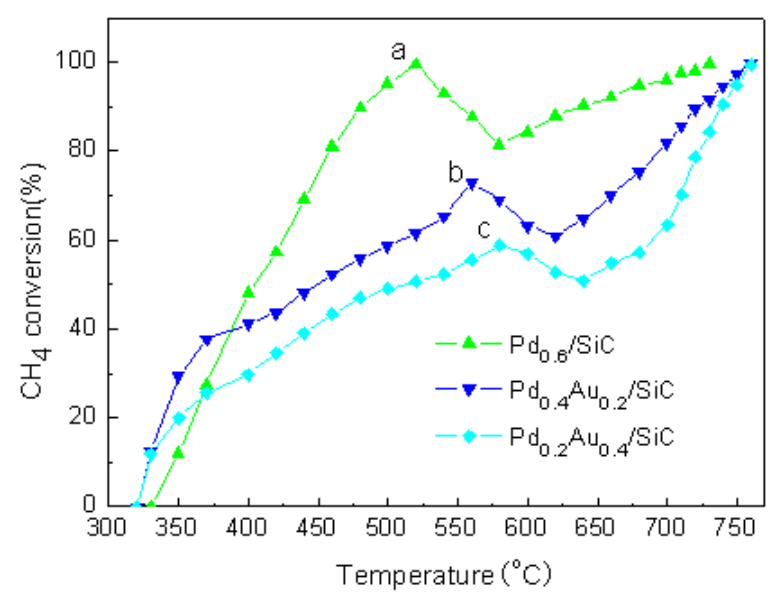

Fig.2 Catalytic activities of $\mathrm{Pd}_{0.6} / \mathrm{SiC}, \mathrm{Pd}_{0.4} \mathrm{Au}_{0.2} / \mathrm{SiC}$ and $\mathrm{Pd}_{0.2} \mathrm{Au}_{0.4} / \mathrm{SiC}$ for methane combustion.
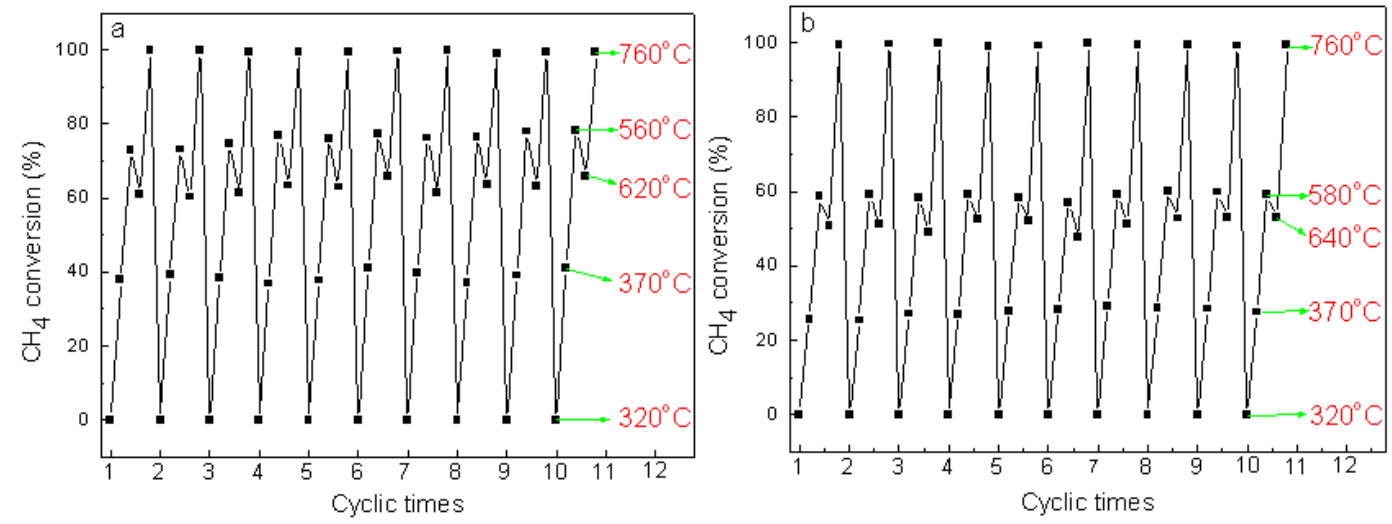

Fig.3 Catalytic stabilities of $\mathrm{Pd}_{0.4} \mathrm{Au}_{0.2} / \mathrm{SiC}$ (a) and $\mathrm{Pd}_{0.2} \mathrm{Au}_{0.4} / \mathrm{SiC}$ (b) for methane combustion. 

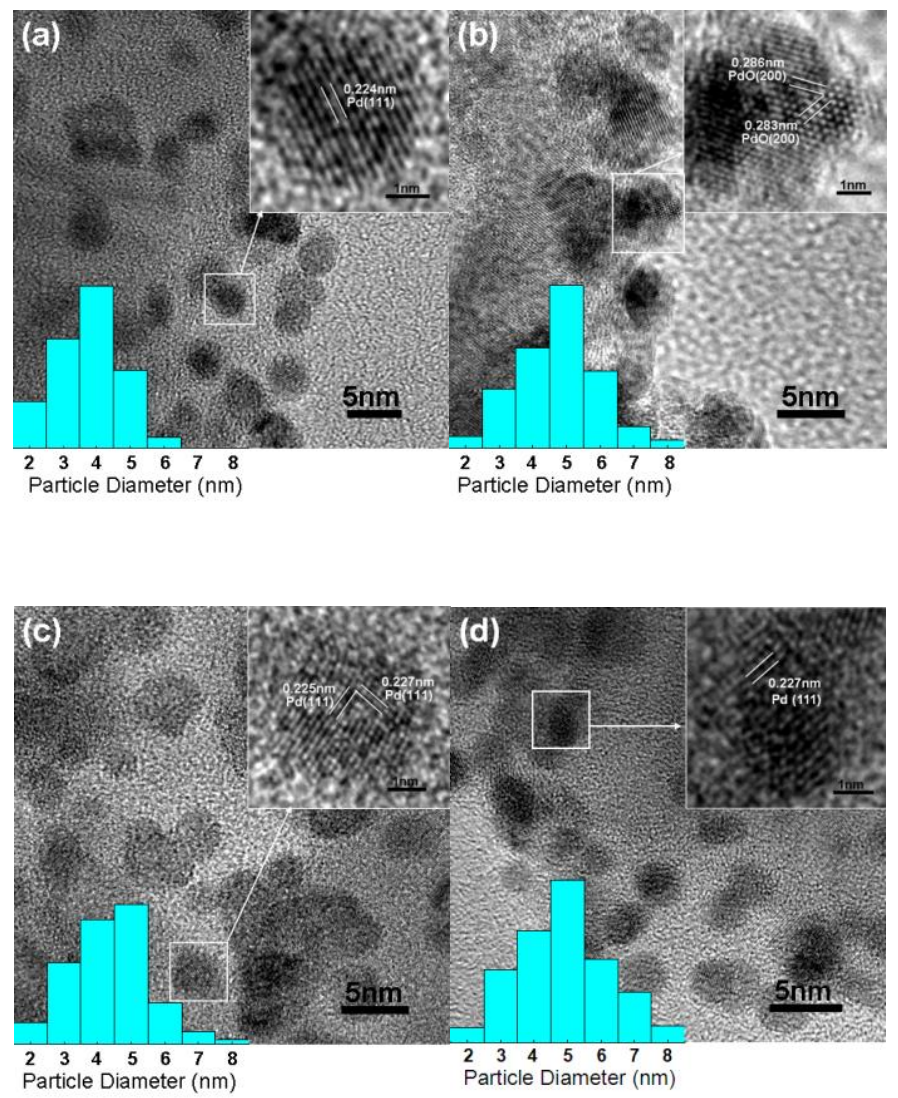

Fig.4 HRTEM images of fresh (a) and used $\mathrm{Pd}_{0.6} / \mathrm{SiC}$ catalysts which were taken at $500^{\circ} \mathrm{C}$ (b), $560^{\circ} \mathrm{C}$ (c) and $730^{\circ} \mathrm{C}$ (d) respectively in the $\mathrm{CH}_{4}$ methane catalytic combustion reaction; and the size distribution of the nanoparticles. 

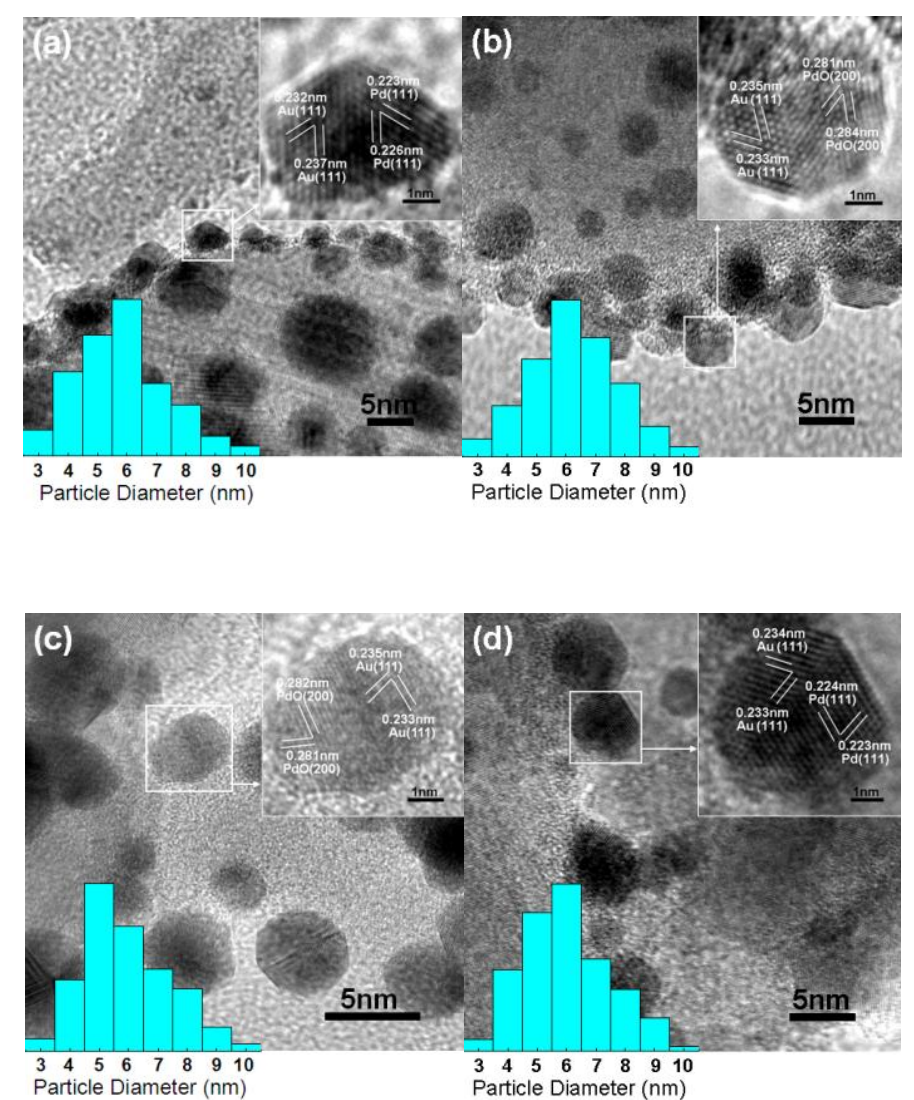

Fig.5 HRTEM images of fresh (a) and used $\mathrm{Pd}_{0.4} \mathrm{Au}_{0.2} / \mathrm{SiC}$ catalysts which were taken at $560^{\circ} \mathrm{C}(\mathrm{b}), 600^{\circ} \mathrm{C}$ (c) and $760^{\circ} \mathrm{C}$ (d) respectively in the $\mathrm{CH}_{4}$ methane catalytic combustion reaction; and the size distribution of the nanoparticles. 

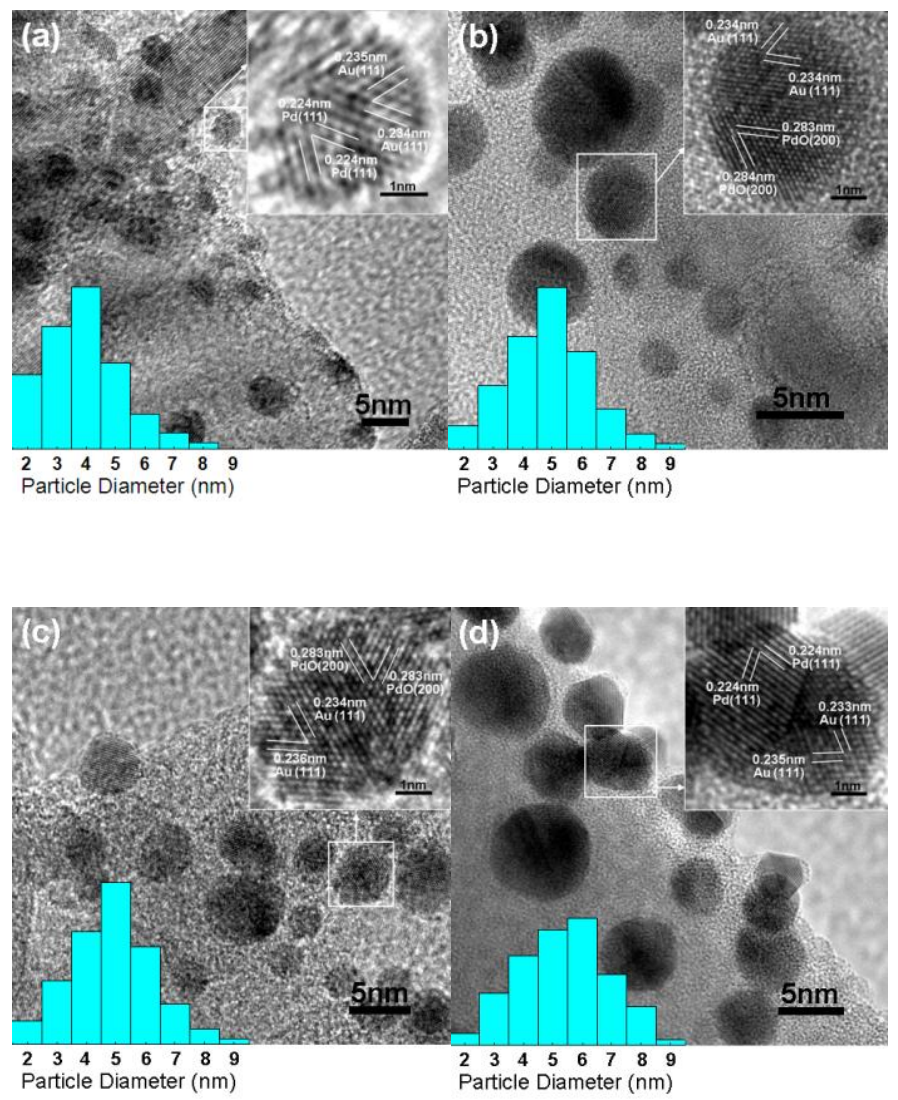

Fig.6 HRTEM images of fresh (a) and used $\mathrm{Pd}_{0.2} \mathrm{Au}_{0.4} / \mathrm{SiC}$ catalysts which were taken at $560^{\circ} \mathrm{C}(\mathrm{b}), 600^{\circ} \mathrm{C}$ (c) and $760^{\circ} \mathrm{C}$ (d) respectively in the $\mathrm{CH}_{4}$ methane catalytic combustion reaction; and the size distribution of the nanoparticles. 

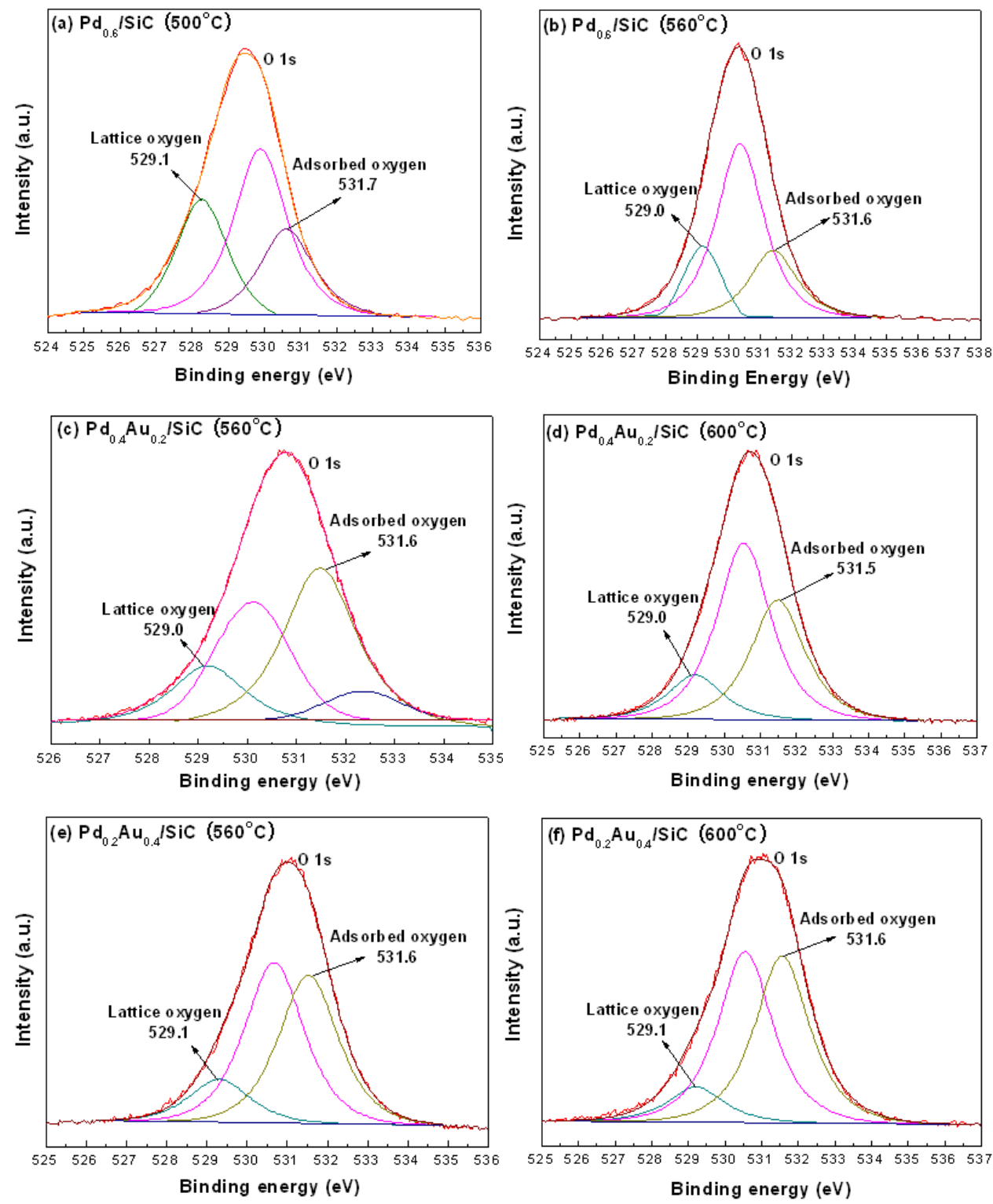

Fig.7 XPS spectra of $\mathrm{O} 1 \mathrm{~s}$ of $\mathrm{Pd}_{0.6} / \mathrm{SiC}, \mathrm{Pd}_{0.4} \mathrm{Au}_{0.2} / \mathrm{SiC}$ and $\mathrm{Pd}_{0.2} \mathrm{Au}_{0.4} / \mathrm{SiC}$ catalysts at different temperatures. 